\title{
Does selecting for improved growth affect wood quality of Pinus pinaster in Portugal?
}

\author{
Maria João Gaspar a,*, José Luís Lousada ${ }^{\mathrm{b}}$, José Carlos Rodrigues ${ }^{\mathrm{c}}$, Alexandre Aguiar ${ }^{\mathrm{d}}$, \\ Maria Helena Almeida ${ }^{\mathrm{e}}$ \\ ${ }^{a}$ Universidade Trás-os-Montes e Alto Douro, Dep. Florestal, Centro de Estudos Florestais, 5001-801 Vila Real, Portugal \\ ${ }^{\mathrm{b}}$ Centro de Investigação e de Tecnologias Agro-Ambientais e Biológicas, Dpto Florestal, Universidade Trás-os-Montes e Alto Douro (UTAD), Portugal \\ ' Instituto Investigação Científica Tropical (IICT) Tapada da Ajuda 1349-01, Portugal \\ ${ }^{\mathrm{d}}$ INIA - Instituto Nacional de Recursos Biológicos, Quinta do Marquês, Portugal \\ e Universidade Técnica de Lisboa, Instituto Superior de Agronomia, Centro de Estudos Florestais, Portugal
}

\section{A R T I C L E I N F O}

\section{Article history:}

Received 1 February 2009

Received in revised form 24 March 2009

Accepted 26 March 2009

\section{Keywords:}

Pinus pinaster

Genetics

Growth

Wood quality

\begin{abstract}
A B S T R A C T
The selection criteria for the first generations in the Portuguese Pinus pinaster improvement program have been the growth rate and form traits. In this work we study the consequences of this selection on wood quality traits. This study assesses genetic and phenotypic correlation between growth, wood density components, lignin content and mechanical traits (radial modulus of elasticity and radial modulus of rupture) of 46 half sib families from a progeny trail located in Leiria, Portugal, originated from seed collected in a clonal seed orchard. A total of 552 seventeen-years-old trees (about half of full rotation age) were sampled at $2 \mathrm{~m}$ height. Height measured at 12 years old presented a higher genetic control $\left(h^{2}=0.34\right)$ relatively to $\mathrm{DBH}$, measured at 12 and 17 years old respectively $\left(h^{2}=0.17\right.$ and $h^{2}=0.15$ ). The results of this study also showed that $\mathrm{DBH}$ growth is more dependent on latewood components than earlywood components and that higher growth in Mediterranean regions can be due to an increase of the period of latewood formation. Further, we can conclude genetic selection based on growth will not result in a decrease of wood density, will not affect the occurrence of spiral grain, and is possible to obtain an increase in the radial modulus of elasticity. The present study also showed that it is possible to select for increased growth with lower lignin proportion. Results also suggest that selection for growth at 12 years will probably not affect negatively the wood properties at 17 years.
\end{abstract}

(c) 2009 Elsevier B.V. All rights reserved.

\section{Introduction}

Maritime pine (Pinus pinaster Ait.) is a highly valuable coniferous species (Pinaceae), broadly distributed in the western Mediterranean Basin, in Southern Europe and Africa, and the Atlantic coast of Portugal, Spain and France (Alía and Martín, 2003). It is one of the most important forest species in France, Portugal and Spain, used mainly for carpentry, construction, chipboard, pulp and paper production, floor boards and palettes. In Portugal, according to the National Forest Inventory (2005/2006), 23\% of the national forest area is occupied by $P$. pinaster (DGRF, 2007), representing $11 \%$ of the total of forest product exports in 2000 (Correia et al., 2004). Due to the economic importance of $P$. pinaster, a national tree improvement plan for this species has been in operation since the early 1980 s (Roulund et al., 1988). Presently, the maritime pine breeding programme is in its second generation of selection (the progeny

\footnotetext{
* Corresponding author. Tel.: +351 259350883; fax: +351 259350859.

E-mail address: mjgaspar@utad.pt (M.J. Gaspar).
}

trials reported in this study are part of this programme), and the selection criteria for the first generations have been the growth rate and form traits. Such selection criteria might have an indirect effect on wood properties (Zobel and Jett, 1995), therefore, it's essential to know the nature and magnitude of the relationship between growth traits, wood density and other quality traits. The relationship between growth rate and wood density has been studied intensively, but the results obtained are contradictory. Zobel and van Buijtenen (1989) reviewed 55 hard pine studies up until 1986; 35 showed no relationship, 11 a significant reduction in density with increased growth and 4 reported that when trees grew faster, a higher density was observed. Wu et al. (2008) reviewed several studies on Pinus radiata and found that in a total of 64 genetic correlations between density and $\mathrm{DBH}$ (or ring width) the values ranged between -1.08 and 0.6 with a mean value of -0.51 .

More attention has been given to breeding for wood density and quality in recent years, because of shorter rotations and the recognition that increasing rotation markedly raises the effective growing cost (Wu et al., 2008). In a previous work by Gaspar et al. (2008a) on the heritability of wood density components in 
$P$. pinaster, it was concluded that ring density (RD) was the trait under strongest genetic control $\left(h^{2}=0.63\right)$, and heritability values of earlywood components exceeded those of latewood components. Heritabilities increased with ring number from pith for almost all wood-density components, and there were high age-age genetic correlations for wood density traits $\left(r_{g}>0.98\right)$.

Sound knowledge of genetic correlations is important for both defining breeding goals and selecting right genotypes (Kumar et al., 2008). If improving one desired characteristic results in a reduced value for a second desirable property, a very careful consideration must be made as to the most effective breeding plan (Zobel and van Buijtenen, 1989). Consequently it is important to avoid problems derived from adverse correlations.

The aim of this study was to estimate genetic and phenotypic correlations between growth and wood quality traits and to evaluate the possible consequences of selection for growth at early ages on wood quality of maritime pine populations in Mediterranean conditions. These findings are of great importance for the continued development of maritime pine breeding programmes, providing a guideline to future generation's selection.

\section{Materials and methods}

\subsection{Location}

The field trial location was at Pinhal de Leiria, established in 1987 and situated in central coastal Portugal (latitude $39^{\circ} 50^{\prime}$, longitude $8^{\circ} 55^{\prime}$, alt $30 \mathrm{~m}$ ). The site is characterized by a Mediterranean climate, with a mean air temperature between $12.5^{\circ} \mathrm{C}$ and $15{ }^{\circ} \mathrm{C}$, relative humidity between 80 and $85 \%$ and yearly rainfall values of $700 \mathrm{~mm}$ to $800 \mathrm{~mm}$, with a 4-month period of summer drought. The Spodic Podzols (PZ sd) soils are derived from sands dunes of maritime origin. Seedlings were nursery raised for 9 months in plastic bags $\left(250 \mathrm{~cm}^{3}\right.$ volume). Planting ( $2 \mathrm{~m} \times 2 \mathrm{~m}$ spacing) took place in March 1987 after harrowing and ploughing the site; no fertilizer was applied.

\subsection{Genetic material}

The progeny test used in this study was established in 1987 . The trial includes 46 open-pollinated families, derived from seed collected in the Escaroupim clonal seed orchard II. The ortets were obtained from plus-trees selected in the Mata Nacional de Leiria by senior forester D.H. Perry in 1963-1964. The selection criteria used were based on volume, stem form, spiral grain and branch habits (Perry and Hopkins, 1967). This seed orchard includes 49 genotypes; it was established by grafting in 1975-1980 and belongs to the first generation of the breeding program. Only 46 families were considered in order to avoid poor seed production. The 46 families were replicated in 8 blocks with $2 \times 4$ trees plots. In 2004, wood samples were collected from a subset of 12 trees for every family in 3 blocks, giving a total number of 552 trees (the four trees per plot were selected by random). A single wood disc with a thickness of $10 \mathrm{~cm}$ was collected at a predetermined sampling height of $2 \mathrm{~m}$. The disk was sawn into a $2 \mathrm{~mm}$-thick radial strip segment from the pith to the bark, and then conditioned at $12 \%$ moisture content. Radial samples were X-rayed perpendicular to the transverse section and their images scanned by microdensitometric analysis (Hughes and Sardinha, 1975; Polge, 1978). The time of exposure to radiation was $300 \mathrm{~s}$, at an intensity of $18 \mathrm{~mA}$ and an accelerating tension of $12 \mathrm{kV}$, with a $2.5 \mathrm{~m}$ distance between X-ray source and film. The data comprising the radial density profiles were recorded every $100 \mu \mathrm{m}$ with a slit height (tangential direction) of $455 \mu \mathrm{m}$.

The first and last annual rings of each sample were excluded since they were usually incomplete. Growth-ring boundaries were identified on the radial profiles by locating the sharp density variations through visual observation of the macroscopic anatomical features. For each ring, average ring density, minimum density (MND), maximum density (MXD), earlywood density (EWD), latewood density (LWD), earlywood width (EWW), latewood width (LWW), ring width (RW) and latewood percentage (LWP) were determined. The earlywood (EW) latewood (LW) boundary in each growth ring was assigned a fixed density of $500 \mathrm{~kg} \mathrm{~m}^{-3}$ as the limit between EW/LW. We used one fixed value of density as has been used for several conifer species (Barbour et al., 1994; Fujimoto et al., 2006), even though some researchers have been using the average of minimum and maximum ring density to define the transition point for EW/LW (Nicholls et al., 1980; Vargas-Hernandez and Adams, 1991; Zamudio et al., 2005). The advantages of this criterion for the EW/LW boundary based on a fixed density value were well explained by Rudman (1968) and Jozsa et al. (1987). This value of $500 \mathrm{~kg} \mathrm{~m}^{-3}$ was a result of an adjustment to the value proposed by Louzada (2000) for $P$. pinaster, where it compares different criteria and indicates that this one is the most correct for this species with 18 years old. Although this criterion does not allow identifying the beginning of the latewood, it allows indentifying the portions of the ring with a density higher than a threshold, which we call LW. Intra-ring density variation was quantified by the heterogeneity index (HI) proposed by Ferrand (1982), defined by the standard deviation of all density values across the annual ring. Because rings close to the pith have less volume than those near the bark, they contribute less to the whole disc volume. To compensate for this effect, wood density components were weighed for each ring density component by its respective cross-sectional area. These area-weighed cumulated traits are henceforth referred to simple as cumulated traits or values (Hylen, 1999).

The same strips were used to evaluate the radial modulus of elasticity $\left(\mathrm{MOE}_{\mathrm{Rad}}\right)$ and the radial modulus of rupture $\left(\mathrm{MOR}_{\mathrm{Rad}}\right)$, through three-point bending tests (Brancheriau et al., 2002). Before testing the specimen dimensions (thickness and width) were measured with a digital calliper $(0.01 \mathrm{~mm}$ resolution). Bending tests were carried out in an electro-mechanical testing machine (Instron 5848 MicroTester $^{\mathbb{R}}$ ). The experiments were carried out at room temperature under displacement control $(0.5 \mathrm{~mm} / \mathrm{min})$ and with a span of $40 \mathrm{~mm}$.

The other traits assessed were spiral grain (SPG) determined for all trees as explained in Gaspar et al. (2008b) In each disc, the grain angle was measured at the most recent formed latewood of the last ring, using a grain slope detector (Harris, 1989) and the pith as a reference (Hannrup et al., 2002).

The proportion of lignin content (LG) was estimated by near infrared spectroscopy (NIR) on extractive-free wood meal samples according to Rodrigues et al. (2006) and Perez et al. (2007). Being an indirect method, NIR needs calibration. The accuracy of NIR spectroscopy is influenced by the spectral noise and the reference data noise (Geladi, 2002). However statements such as "NIR predictions can never be better than the primary reference method" were refuted (DiFoggio, 1995; Rodrigues et al., 2006).

Height (HT) was assessed with a telescopic rod at age 12, and breast height diameter (DBH) was measured over bark using standard procedures, at age 12 and 17 , in all trees of the trial.

\subsection{Data analysis}

The mixed linear model associated with the data for a given trait was:

$Y_{i j k}=\mu+B_{j}+F_{i}+B \times F_{i j}+\varepsilon_{i j k}$

where $Y$ represents the phenotypic individual observation; $\mu$ is the overall mean; $B_{j}$ : the effect of the $j$ th block (fixed); $F_{i}$ : the effect of 
the $i$ th family (random); $B \times F_{i j}$ : the effect of the interaction between the $i$ th family and the $j$ th block (random) and $\varepsilon$ : the residual error. All terms in the model 1, except $B$, is assumed to be normally and independently distributed with mean zero and corresponding variances $\left(\sigma^{2}\right)$. Variance components for family $\left(\sigma_{f}^{2}\right)$, family-block interaction $\left(\sigma_{f \times b}^{2}\right)$ and residual errors $\left(\sigma_{\varepsilon}^{2}\right)$, with the respective associated standard errors, were estimated by restricted maximum likelihood, using the average information REML algorithm implemented in the ASREML programme (Gilmour et al., 1998).

Narrow sense heritability $\left(h^{2}\right)$ was calculated for each trait as:

$h^{2}=\frac{\sigma_{a}^{2}}{\sigma_{P}^{2}}$

where $\sigma_{a}^{2}$ represents the additive genetic variance and $\sigma_{P}^{2}$ the total phenotypic variance. Total phenotypic variance was estimated as:

$\sigma^{2} P=\sigma_{f}^{2}+\sigma_{f \times b}^{2}+\sigma_{\varepsilon}^{2}$.

and estimated additive variances as:

$\sigma_{a}^{2}=\frac{1}{2 \theta} \times \sigma_{f}^{2}$

where the coancestry coefficient $(\theta=0.13)$ was obtained (in the absence of selfing) from correlated paternity $r_{p}{ }^{\prime}$ estimated by molecular markers see (Gaspar et al., 2008c) as:

$\theta=0.250 \times r_{p}{ }^{\prime}+0.125 \times\left(1-r_{p}{ }^{\prime}\right)$

Standard errors for heritability were estimated by ASREML using a Taylor series approximation (Gilmour et al., 1998).

Genetic and phenotypic correlations between all wood traits were calculated using a multivariate extension of model (1). When the family effect was found to be null for any of the traits analysed in the univariate analysis, this effect was not included in the multivariate analysis. Genetic correlations between traits ( $X$ and $Y$ ) were evaluated as follows:

$r_{g}=\frac{\operatorname{cov}_{a}(x, y)}{\sqrt{\sigma_{a x}^{2} \cdot \sigma_{a y}^{2}}}$

where $\operatorname{cov}_{a}(x, y)$ is the additive genetic covariance, and $\sigma_{a x}^{2}$ and $\sigma_{a y}^{2}$ are the additive variance components for traits $X$ and $Y$, respectively.

The phenotypic correlation between traits $(X$ and $Y$ ), was estimated as:

$r_{p}=\frac{\operatorname{cov}_{P}(x, y)}{\sqrt{\sigma_{P x}^{2} \cdot \sigma_{P y}^{2}}}$

where $\operatorname{cov}_{P}(x, y)$ is the phenotypic covariance between traits $X$ and $Y$, estimated as $\operatorname{cov}_{P}(x, y)=\operatorname{cov}_{f}(x, y)+\operatorname{cov}_{f b}(x, y)+\operatorname{cov}_{\varepsilon}(x, y)$, which is the sum of the family, interaction, and residual covariance components. $\sigma_{P X}^{2}$ and $\sigma_{P y}^{2}$ are the phenotypic variances for traits $X$ and $Y$, respectively. Standard errors for genetic and phenotypic correlations were estimated by ASREML a Taylor series approximation (Gilmour et al., 1998).

Selecting for one trait $x$ will result in a correlated response of other traits, and the correlated response of a trait $y$ can be estimated by using the equation of indirect response (Falconer and Mackay, 1996):

$C r_{y / x}=i \cdot h_{x} \cdot h_{y} \cdot r_{g(x y)} \cdot \sigma_{P y}$

where $h_{x}$ and $h_{y}$ are the square root of appropriate narrow sense heritabilities for traits $X$ and $Y$ respectively; $r_{g(x y)}$ is the additive genetic correlation between traits $X$ and $Y$ and $\sigma_{P y}$ is the phenotypic standard deviations of trait $y$.
Table 1

Descriptive statistics table for diameter measured at 17 and 12 years old and total height measured at 12 years old, respective narrow heritability $\left(h^{2}\right)$ estimates and phenotypic and additive variances ( $V_{a}$ and $V_{P}$, respectively).

\begin{tabular}{lccc}
\hline & $\mathrm{DBH}_{12}(\mathrm{~cm})$ & $\mathrm{HT}_{12}(\mathrm{~m})$ & $\mathrm{DBH}_{17}(\mathrm{~cm})$ \\
\hline Mean & 10.28 & 6.9 & 13.26 \\
$\mathrm{SD}$ & 2.66 & 1.16 & 3.20 \\
$\mathrm{CV}(\%)$ & 29 & 18 & 27 \\
Max & 18.0 & 10.0 & 22.0 \\
Min & 5.0 & 9.0 & 5.1 \\
$V_{a}$ & 1.15 & 0.41 & 1.50 \\
$V_{P}$ & 6.68 & 1.19 & 9.80 \\
$h^{2}$ & $0.17(0.06)$ & $0.34(0.10)$ & $0.15(0.05)$ \\
\hline
\end{tabular}

Standard errors given in brackets.

$\mathrm{DBH}_{12}=$ diameter measured at 12 years old; $\mathrm{HT}=$ total height measured at 12 years old; $\mathrm{DBH}_{17}=$ diameter measured at 17 years old.

\section{Results and discussion}

Summary statistics for growth traits and respective heritability estimates are given in Table 1.

Results showed a lower heritability for DBH $\left(h_{(12)}^{2}=0.17\right.$ and $\left.h_{(17)}^{2}=0.15\right)$ compared to HT $\left(h^{2}=0.34\right)$ because the phenotypic variance is relatively higher than the additive variance.

Results for DBH are in agreement with those observed for the same species by Kusnadar et al. (1998) and Zas et al. (2004), but lower than those found by Costa and Durel (1996). Our estimated heritabilities for HT correspond well with those found in previous studies of maritime pine [0.27-0.45] (Kremer and Lascoux, 1988; Danjon, 1995; Pot et al., 2002), but lower values [0.11-0.17] for this trait were observed by (Kusnadar et al., 1998; Zas et al., 2004). Although a higher genetic control of HT relatively to DBH was reported by Zas et al. (2004), other authors have suggested the opposite (Costa and Durel, 1996; Kusnadar et al., 1998); i.e. higher heritability values for DBH. According to Costa and Durel (1996) diameter is more affected by competition between trees and microenvironment effects than height. In fact, larger additive and phenotypic variances observed for DBH were observed in this work. Contributing to this higher competition between trees may the fact that this trial was installed with a narrower spacing $(2 \times 2)$ than usual for this species.

Relatively small changes in DBH heritability with age $(0.17$ versus 0.15), were also observed by Danjon (1994), Costa and Durel

Table 2

Phenotypic $\left(r_{p}\right)$ and additive genetic $\left(r_{g}\right)$ correlations between diameter measured at 17 years old and the other wood traits.

\begin{tabular}{llr}
\hline & \multicolumn{1}{l}{$r_{p}$} & \multicolumn{1}{l}{$r_{g}$} \\
\hline RD & $0.24(0.04)$ & $0.04(0.32)$ \\
MND & $0.00(0.04)$ & $-0.05(0.22)$ \\
MXD & $0.24(0.04)$ & $0.04(0.25)$ \\
EWD & $0.07(0.05)$ & $-0.04(0.22)$ \\
LWD & $0.20(0.05)$ & $-0.09(0.28)$ \\
LWP & $0.33(0.04)$ & $0.24(0.22)$ \\
EWW & $0.00(0.05)$ & $-0.17(0.26)$ \\
LWW & $0.42(0.04)$ & $0.13(0.25)$ \\
SPG & $0.24(0.04)$ & $0.15(0.23)$ \\
MOR $_{\text {rad }}$ & $0.07(0.05)$ & $-0.02(0.25)$ \\
MOE $_{\text {rad }}$ & $0.49(0.03)$ & $0.30(0.24)$ \\
LG & $-0.19(0.05)$ & $-0.41(0.23)$ \\
\hline
\end{tabular}

Values in brackets are the standard error for the genetic correlations.

$\mathrm{DBH}_{17}=$ diameter measured at 17 years old; $\mathrm{RD}=$ average ring density, $\mathrm{MND}=$ minimum density, $\mathrm{MXD}=$ maximum density EWD = earlywood density, LWD = latewood density, $L W P=$ latewood percentage, EWW = earlywood width, LWW = latewood width, $\mathrm{SPG}=$ spiral grain; $R_{\mathrm{rad}}=$ radial modulus of rupture; $\mathrm{MOE}_{\mathrm{rad}}=$ radial modulus of elasticity; $L G=$ proportion of lignin content. 
(1996) and Kusnadar et al. (1998) although most of these authors mentioned that heritability increases with age.

Phenotypic $\left(r_{p}\right)$ and additive genetic $\left(r_{g}\right)$ correlations between DBH measured at 17 years old and the other wood traits are presented in Table 2.

In contrast to Picea species, where negative genetic correlation between wood density and growth traits is usually reported (Yanchuk and Kiss, 1993; Zhang et al., 1996; Hannrup et al., 2004), studies on several Pinus species have revealed often contrasting results (Zobel and Jett, 1995; Fries and Ericsson, 2006; Wu et al., 2008). Even in P. pinaster, correlation values between wood density and growth rate are contradictory. While Keller (1973) and Louzada (2003) obtained positive correlations between density and growth (0.43 and 0.11 respectively), Pot et al. (2002) and Chaperon et al. (1989) found negative genetic correlations in the same species $(-0.48$ and -0.89$)$. For $P$. pinaster in France Bouffier et al. (2008), reported that these two traits were weakly negatively correlated both phenotypically and genetically. In the present study, phenotypic correlations between $\mathrm{DBH}_{17}$ and $\mathrm{RD}$ were weakly positive $(0.24)$ but genetic correlation was close to zero (0.04), indicating that selection based on growth will not result in a decrease of wood density.

In a comprehensive review on the reasons for these contradictory results, Louzada (2003) suggested that the relationship between wood density and growth rate is site specific. From our data (Table 2) it can be observed that DBH was more dependent on Latewood components (MXD, LWD) than Earlywood components (MND, EWD). Increase in $\mathrm{DBH}_{17}$ was due to an increase in LWP (0.42) and not an enhancement in $\operatorname{EWW}(0.0)$. Further, it is clear that larger trees tended to present higher values of RD, LWD, LWW and LWP, explaining why faster growing trees do not have necessarily lower densities. Results suggest that one possible reason for higher or lower wood density in fast growing trees depends upon growth being due to an increase of LWW or EWW, respectively. In a study on Abies balsamea Koga and Zhang (2004) reported a negative phenotypic correlation between RD and RW $(-0.48)$, a strong positive correlation between RW and EW (0.96), but no correlation between RW and LW (0.05), i.e. larger radial growth was caused by an increase in EW. In Picea abies Steffenrem (2008) refers that RW variation can be explained by earlywood zone width, while the width of the latewood barely varies. The existence of more LW or EW can be associated with the growing conditions of trees. Higher growth rates observed in higher latitudes can be a consequence of the early onset of cambial initiation, resulting in a higher proportion of EW. On the other hand, higher growth in Mediterranean regions can be due to an increase of the period of latewood formation, since the main tree growth constraining factors in this region are the high temperatures and water stress during the summer. When growth conditions are favourable in summer (water availability), trees present higher RW due to an enlargement of LWW and, consequently, higher RD. Conversely, during drought summers trees will present less LWW, RW and RD. A significant association of $P$. pinaster growth with water supply was observed in a study performed in central Spain (Bogino and Bravo, 2008). Also for three pine species ( $P$. sylvestris, $P$. nigra and $P$. uncinata) a positive effect of summer rainfall on growth has also been observed in Spain and Portugal (Andreu et al., 2007).

Also Campelo et al. (2007) in a study performed in $P$. pinea in Portugal, verified that climate explained between 59 and $76 \%$ of the tree ring variance, that latewood width was more sensitive to climate variations than earlywood and that earlywood development was mostly pre-determined at the beginning of the growing season. Moreover, results from a previous work (Gaspar et al., 2008a), performed on the same samples used in this study, showed that heritability estimates for earlywood components
$\left(h_{(\mathrm{MND})}^{2}=0.54, h_{(\mathrm{EWD})}^{2}=0.60\right)$ were superior to those obtained for latewood components $\left(h_{(\mathrm{MXD})}^{2}=0.34, h_{(\mathrm{LWD})}^{2}=0.26\right.$, confirming that for $P$. pinaster earlywood characteristics are subject to stronger genetic control and that latewood components are more subject to environmental factors. Earlywood formation is made partially at the expense of stored carbohydrates rather that products of current photosynthesis (Hill et al., 1995), while latewood formation depends mainly on current photosynthesis and, hence latewood traits are more closely related to current climate conditions that earlywood (Zhang, 1997; Lebourgeois, 2000).

The relationship between wood density and growth also differs with location to some extent some extent (Zhang et al., 1996). To this author it seems that in a species where exists a negative relationship between wood density and growth this relation tends to be weaker in trees growing in a more favourable environment. For Downes et al. (2002) and Wimmer and Downes (2003) it is evident that the relationship between annual growth rate and density will depend largely on the relative size of the increments produced at different times of the year. These authors stated that when large rings are accompanied with the increased proportion of latewood, a positive relationship between density and growth is also possible.

It is important to point out that in order to assess the real influence of growth rate on wood density, analyses must be carried out among homogeneous age classes. According to Zobel and van Buijtenen (1989) it is not acceptable to relate wood properties to ring width with rings of different ages. Nevertheless, this has been and still is frequently done, resulting in false and controversial ideas on the effect of growth rate, and may be another factor contributing for multiplicity of results obtained. It is of great importance to define difference between juvenile and mature wood when studying the effect of growth rate on basic density (Saranpää, 2003). Wide growth rings and low density are associated with juvenile wood, and narrow growth rings with high density are characteristic for mature wood. Therefore, a negative correlation between ring width and density will be evident if juvenile and mature wood are both included in the analysis (Saranpää, 2003).

Formation of spiral grain is under considerable genetic control, while its expression may be at least partly dependent on factors affecting the growth conditions of trees (Harris, 1989). Other works have revealed high level of spiral grain to be correlated with a fast growth rate (Eklund et al., 2003). These authors demonstrated a positive relationship between growth, ethylene evolution and a high left-handed spiral grain. Results from this work indicate the existence of a positive but low phenotypic and genetic correlation between growth and spiral grain ( 0.24 and 0.15 respectively), indicating that grain inclination tend to be maintained in fast growing trees. Similar findings were reported for $P$. abies by Costa e Silva et al. (2000) and Hallingback et al. (2008). Lower but inconsistent correlations were obtained for Pinus caribaea (Harding et al., 1991), Pinus sylvestris (Hannrup et al., 2003) and P. abies (Hansen and Roulund, 1997; Hannrup et al., 2003).

As observed in the present work, phenotypic correlations between these traits were higher than genetic ones, meaning that the relation between spiral grain and growth traits is more influenced by environmental conditions than genetic conditions. Thus, selecting for fast growing trees will not affect the occurrence of spiral grain since environmental conditions can exert a more pronounced effect.

Correlations between growth and mechanical traits highlighted a modereate positive phenotypic correlation between diameter growth and $\mathrm{MOE}_{\mathrm{Rad}}(0.49)$ while genetic correlation, although also positive, presented a more moderate value $(0.30)$. For $M_{\text {Rad }}$ a very weak positive phenotypic correlation was obtained $(0.07)$ 
Table 3

Phenotypic $\left(r_{p}\right)$ and additive genetic $\left(r_{g}\right)$ correlations between different wood traits and DBH (diameter) and HT (total height) measured at 12 years old.

\begin{tabular}{lrrrrr}
\hline & \multicolumn{2}{l}{$\mathrm{DBH}_{12}$} & & \multicolumn{2}{l}{$\mathrm{HT}_{12}$} \\
\cline { 2 - 3 } \cline { 5 - 6 } & \multicolumn{1}{r}{$r_{p}$} & \multicolumn{1}{c}{$r_{g}$} & \multicolumn{1}{l}{$r_{p}$} & \multicolumn{1}{l}{$r_{g}$} \\
\hline RD & $0.25(0.04)$ & $0.11(0.21)$ & & $0.31(0.04)$ & $0.06(0.19)$ \\
MND & $-0.14(0.05)$ & $0.09(0.21)$ & & $0.11(0.05)$ & $-0.05(0.19)$ \\
MXD & $0.25(0.04)$ & $0.03(0.24)$ & & $0.29(0.04)$ & $-0.01(0.22)$ \\
EWD & $0.08(0.05)$ & $0.05(0.21)$ & & $0.13(0.05)$ & $-0.03(0.19)$ \\
LWD & $0.21(0.04)$ & $-0.08(0.27)$ & & $0.25(0.04)$ & $-0.08(0.24)$ \\
LWP & $0.32(0.04)$ & $0.29(0.21)$ & & $0.36(0.04)$ & $0.25(0.20)$ \\
EWW & $-0.05(0.05)$ & $-0.32(0.24)$ & & $-0.13(0.04)$ & $-0.13(0.32)$ \\
LWW & $0.40(0.04)$ & $0.14(0.24)$ & & $0.37(0.04)$ & $0.23(0.21)$ \\
SPG & $0.20(0.04)$ & $0.22(0.21)$ & & $0.12(0.05)$ & $0.17(0.20)$ \\
MOR & $0.03(0.05)$ & $-0.14(0.24)$ & & $0.04(0.05)$ & $-0.11(0.22)$ \\
MOE & $0.44(0.04)$ & $0.16(0.25)$ & & $0.41(0.04)$ & $0.29(0.22)$ \\
LG & $-0.23(0.04)$ & $-0.31(0.24)$ & & $-0.28(0.04)$ & $-0.42(0.23)$ \\
\hline
\end{tabular}

Note: see Table 2 for abbreviations.

while the genetic correlation presented a weak but negative value. Several works on $P$. radiata (Kumar et al., 2002; Kumar, 2004; Baltunis et al., 2007), Pseudotsuga menziesii (Johnson and Gartner, 2006) and P. abies (Steffenrem, 2008) gave negative correlations between growth and modulus of elasticity, but it should be highlighted that the mechanical traits were evaluated in the longitunal direction in these studies. Results from a previous work (Gaspar et al., submitted for publication-b) performed on the same samples used in the present study, indicated that $\mathrm{MOE}_{\text {Rad }}$ was more dependent on latewood components, either the density (MXD and LWD) or growth components (LWP and LWW). The higher positive genetic correlation observed in this work was between $\mathrm{MOE}_{\mathrm{Rad}}$ and $\mathrm{LWW}$, indicating that selecting for and enlargement of the latewood percentage would increase wood stiffness. So, it is possible that LWW, which also has a high association with growth rate, is responsible for the positive correlation between growth and radial MOE.

Phenotypic and genetic correlations between the DBH and lignin were negative $(-0.19$ and -0.41 , respectively). The moderate to high value obtained for genetic correlation indicates that it is possible to select for increased growth with a lower lignin proportion, which is beneficial to pulp production. This relation can also be explained by the fact that lignin proportion was more dependent on latewood portion presented at the ring (LWP and LWW), suggesting that these traits may be controlled, at least partially by the same set of genes, and that increasing the existence of more latewood would decrease the lignin proportion (Gaspar et al., submitted for publication-a). Thus, trees with higher DBH and higher proportion of Latewood are expected to have lower LG. Results observed in this work are opposite those observed for other conifers including $P$. pinaster where positive genetic correlations were observed between growth traits and lignin proportion (Costa e Silva et al., 1998; Pot et al., 2002; Sykes et al., 2006). These results are understandable since the relation between growth and wood density in these works was negative, and wood density is usually negatively correlated with lignin proportion.

Table 3 presents phenotypic $\left(r_{p}\right)$ and additive genetic $\left(r_{g}\right)$ correlations between wood quality traits evaluated at 17 years old, and DBH and HT measured at 12 years old, while in Table 4 are presented the expected correlated response for each trait considering a selection for growth traits with an intensity of $10 \%$.

Early evaluation of genotypes for adaptative and volume traits are an important component of tree improvement strategy when long rotations are used in forestry. However, attention should be given to the effect of this selection process on wood quality. Our results indicate that since genetic and phenotypic correlations between wood quality traits and growth traits (DBH and HT) at age 17 were of the same order and direction as correlations with the
Table 4

Expected correlated response for each trait considering selection for growth traits with an intensity of $10 \%$, genetic gain give in trait units (GG) and in percent (CG\%).

\begin{tabular}{|c|c|c|c|c|c|c|}
\hline & \multicolumn{2}{|l|}{$\mathrm{HT}_{12}$} & \multicolumn{2}{|c|}{$\mathrm{DBH}_{12}$} & \multicolumn{2}{|l|}{$\mathrm{DBH}_{17}$} \\
\hline & GG & CG\% & GG & CG\% & GG & CG\% \\
\hline $\mathrm{RD}\left(\mathrm{kg} \mathrm{m}^{-3}\right)$ & 0.53 & 11 & 0.64 & 35 & 0.58 & 22 \\
\hline $\operatorname{MND}\left(\mathrm{kg} \mathrm{m}^{-3}\right)$ & 0.27 & -13 & 0.43 & 41 & 0.23 & -26 \\
\hline $\operatorname{MXD}\left(\mathrm{kg} \mathrm{m}^{-3}\right)$ & 0.70 & -1 & 0.74 & 5 & 0.69 & -2 \\
\hline $\operatorname{EWD}\left(\mathrm{kg} \mathrm{m}^{-3}\right)$ & 0.36 & -7 & 0.46 & 19 & 0.34 & -13 \\
\hline $\operatorname{LWD}\left(\mathrm{kg} \mathrm{m}^{-3}\right)$ & 0.57 & -7 & 0.54 & -12 & 0.53 & -14 \\
\hline LWP (\%) & 38.20 & 1 & 38.39 & 1 & 38.38 & -1 \\
\hline EWW (mm) & 2.59 & -3 & 2.34 & -13 & 2.52 & -6 \\
\hline LWW (mm) & 1.69 & 9 & 1.69 & 10 & 1.82 & 18 \\
\hline SPG & 4.27 & 1 & 4.34 & 3 & 4.33 & 3 \\
\hline $\mathrm{MOR}_{\text {rad }}(\mathrm{MPa})$ & 13.61 & -1 & 13.53 & -1 & 13.54 & -1 \\
\hline $\mathrm{MOE}_{\mathrm{rad}}(\mathrm{GPa})$ & 1.32 & 16 & 1.30 & 14 & 1.48 & 30 \\
\hline LG (\%) & 27.86 & -1 & 27.79 & -1 & 27.60 & -2 \\
\hline
\end{tabular}

Note: see Table 2 for abbreviations.

same traits at 12 years old, we can conclude that selection for growth at 12 years will not negatively affect the wood properties at 17 years. In some situations like for RD and EWW, the correlations were higher with $\mathrm{DBH}_{12}(0.11$ and -0.32$)$ than with $\mathrm{DBH}_{17}(0.04$ and -0.17 ), indicating that early selection can be suitable for these traits. The correlated responses presented in Table 4 between these traits corroborate this point; however we have to stress out the high errors associated with the correlation estimates. Concerning the genetic correlations with $\mathrm{HT}_{12}$, all were lower than the ones observed with $\mathrm{DBH}_{12}$, excepting for the correlations with LWW and $\mathrm{MOE}_{\mathrm{Rad}}$, but the expected correlated responses are not very different.

\section{Conclusions}

Based on the results of this study we can conclude that for the $P$. pinaster Portuguese breeding programme a genetic selection based on growth can be performed without a consequent decrease of wood density, it will not affect the occurrence of spiral grain, and is possible to obtain an increase in the radial modulus of elasticity. The present study also showed that it is possible to select for increased growth with lower lignin proportion. Further, our results suggests that for Maritime pine in Mediterranean conditions, DBH growth is more dependent on latewood components that earlywood components, and that an increase in this trait is due to an increase in LWP and not due to an enhancement in EWW. Results also suggest that selection for growth at 12 years will not negatively affect the wood properties at 17 years.

\section{Acknowledgement}

M.J. Gaspar was funded by the Portuguese Foundation for Science and Technology (Doctoral grant SFRH/BD/27412/2006).

\section{References}

Alía, R., Martín, S., 2003. Euforgen. In: Technical Guidelines for Genetic Conservation and Use for Maritime Pine (Pinus pinaster), International Plant Genetic Resources Institute, Rome, p. 6.

Andreu, L., Gutierrez, E., Macias, M., Ribas, M., Bosch, O., Camarero, J.J., 2007. Climate increases regional tree-growth variability in Iberian pine forests. Global Change Biology 13, 804-815.

Baltunis, B.S., Wu, H.X., Powell, M.B., 2007. Inheritance of density, microfibril angle, and modulus of elasticity in juvenile wood of Pinus radiata at two locations in Australia. Canadian Journal of Forest Research 37, 2164-2174.

Barbour, R.J., Fayle, D.C.F., Chauret, G., Cook, J., Karsh, M.B., Ran, S.K., 1994. Breastheight relative density and radial growth in mature Jack Pine (Pinus banksiana) for 38 years after thinning. Canadian Journal of Forest Research 24, 2439-2447.

Bogino, S.M., Bravo, F., 2008. Growth response of Pinus pinaster Ait. to climatic variables in central Spanish forests. Annals of Forest Science 65 
Bouffier, L., Charlot, C., Raffin, A., Rozenberg, P., Kremer, A., 2008. Can wood density be efficiently selected at early stage in maritime pine (Pinus pinaster Ait.)? Annals of Forest Science 65, 106.

Brancheriau, L., Bailleres, H., Guitard, D., 2002. Comparison between modulus of elasticity values calculated using 3 and 4 point bending tests on wooden samples. Wood Science and Technology 36, 367-383.

Campelo, F., Nabais, C., Freitas, H., Gutierrez, E., 2007. Climatic significance of treering width and intra-annual density fluctuations in Pinus pinea from a dry Mediterranean area in Portugal. Annals of Forest Science 64, 229-238.

Chaperon, H., Raoux, H., Siohan, A., Alazard, P., 1989. Variabilité génetique des proprietés technologiques du bois de pin maritime. Annales Afocel, Annales de Recherches sylvicoles 174, 327-345.

Correia, I., Almeida, M.H., Aguiar, A., 2004. Variabilidade do Crescimento e da Forma de Proveniências de Pinus pinaster Aiton aos 8 anos, na Mata Nacional do Escaroupim. Silva Lusitana 12, 151-182.

Costa e Silva, J., Borralho, N.M.G., Wellendorf, H., 2000. Genetic parameter estimates for diameter growth, pilodyn penetration and spiral grain in Picea abies (L.) KARST. Silvae Genetica 49, 29-36.

Costa e Silva, J., Wellendorf, H., Pereira, H., 1998. Clonal variation in wood quality and growth in young sitka spruce (Picea sitchensis (Bong.) Carr.): estimation of quantitative genetic parameters and index selection for improved pulpwood. Silvae Genetica 47, 20-33.

Costa, P., Durel, C.E., 1996. Time trends in genetic control over height and diameter in maritime pine. Canadian Journal of Forest Research 26, 12091217.

Danjon, F., 1994. Stand features and height growth in a 36-year-old Maritime pine (Pinus pinaster Ait) provenance test. Silvae Genetica 43, 52-62.

Danjon, F., 1995. Observed selection effects on height growth, diameter and stem form in Maritime pine. Silvae Genetica 44, 10-19.

DGRF, 2007. Inventário Florestal Nacional 2005/2006. Direcção Geral das Florestas.

DiFoggio, R., 1995. Examination of some misconceptions about near-infrared analysis. Applied Spectroscopy 67-75.

Downes, G.M., Wimmer, R., Evans, R., 2002. Understanding wood formation: gains to commercial forestry through tree-ring research. Dendrochronologia $20,37-$ 51.

Eklund, L., Sall, H., Linder, S., 2003. Enhanced growth and ethylene increases spiral grain formation in Picea abies and Abies balsamea trees. Trees-Structure and Function 17, 81-86.

Falconer, D.S., Mackay, T.F.C., 1996. Introduction to Quantitative Genetics, New York.

Ferrand, J.C., 1982. Réflexions sur la Densité du Bois. 2ère Partie: Calcule de la densité et de son hétérogénéité Holzforschung 36, 153-157.

Fries, A., Ericsson, T., 2006. Estimating genetic parameters for wood density of Scots pine (Pinus sylvestris L.). Silvae Genetica 55, 84-92.

Fujimoto, T., Akutsu, H., Kita, K., Uchiyama, K., Kuromaru, M., Oda, K., 2006. Age trends of genetic parameters of spiral grain in hybrid larch F-1 and implications for efficiency of early selection. Journal of Wood Science 52, 101-106.

Gaspar, M.J., Alves, A., Louzada, J.L., Santos, A., Simões, R., Fernandes, C., Almeida, M.H., Rodrigues, J.C. Phenotypic and genetic correlations between lignin and wood density components in Pinus pinaster AIT. Annals of Forest Science, submitted for publication a.

Gaspar, M.J., de-Lucas, A., González-Martínez, S.C., Paiva, J., Hidalgo, E., Louzada, J.L., Almeida, M.H., Alia, R., 2008c. Coancestry among wind pollinated progenies from a Pinus pinaster seed orchard in a progeny trial. In: D.L. (Ed.), Proceedings of a Seed Orchard Conference, Umeä (http://www.genfys.slu.se/staff/dagl/ Umea07/ZProcFinalFeb08.pdf).

Gaspar, M.J., Lousada, J.L., Morais, J., Fernandes, C., Almeida, M.H. Genetic variations of wood mechanical traits in 46 half-sib families of Pinus pinaster AIT, submitted for publication $b$.

Gaspar, M.J., Louzada, J.L., Aguiar, A., Almeida, M.H., 2008b. Genetic correlations between wood quality traits of Pinus pinaster Ait. Annals of Forest Science 65.

Gaspar, M.J., Louzada, J.L., Silva, M.E., Aguiar, A., Almeida, M.H., 2008a. Age trends in genetic parameters of wood density components in 46 half-sibling families of Pinus pinaster. Canadian Journal of Forest Research 38, 1470-1477.

Geladi, P., 2002. Some recent trends in the calibration literature. Chemometrics and Intelligent Laboratory Systems 60, 211-224.

Gilmour, A., Gogel, B., Cullis, B., Welham, S., Thompson, R., 1998. ASREML Users Manual. VSN International, New south Wales Agriculture, Orange.

Hallingback, H.R., Jansson, G., Hannrup, B., 2008. Genetic parameters for grain angle in 28-year-old Norway spruce progeny trials and their parent seed orchard. Annals of Forest Science 65

Hannrup, B., Cahalan, C., Chantre, G., Grabner, M., Karlsson, B., Le Bayon, I., Jones, G.L., Muller, U., Pereira, H., Rodrigues, J.C., Rosner, S., Rozenberg, P., Wilhelmsson, L., Wimmer, R., 2004. Genetic parameters of growth and wood quality traits in Picea abies. Scandinavian Journal of Forest Research 19, 14-29.

Hannrup, B., Grabner, M., Karlsson, B., Müller, U., Rosner, S., Wilhelmsson, L. Wimmer, R., 2002. Genetic parameters for spiral-grain angle in two 19-yearold clnal Norway spruce trials. Annals of Forest Science 59, 551-556.

Hannrup, B., Säll, H., Jansson, G., 2003. Genetic parameters for spiral grain in Scots pine and Norway spruce. Silvae Genetica 52, 215-220.

Hansen, J.K., Roulund, H., 1997. Genetic parameters for spiral grain stem form, pilodyn and growth in 13 years old clones of Sitka spruce (Picea sitchensis (Bong.) Carr.). Silvae Genetica 46, 107-113.

Harding, K.J., Kanowski, P.J., Woolaston, R.R., 1991. Preliminary genetic parameter estimates for some wood quality traits of Pinus caribaea Var Hondurensis in Queensland, Australia. Silvae Genetica 40, 152-156.
Harris, J.M., 1989. Spiral Grain and Wave Phenomena in Wood Formation, Berlin, Heidelberg, and New York.

Hill, S.A., Waterhouse, J.S., Field, E.M., Switsur, V.R., Aprees, T., 1995. Rapid recycling of triose phosphates in Oak stem tissue. Plant Cell and Environment 18, 931936.

Hughes, J.F., Sardinha, R.M.A., 1975. The application of optical densitometry in the study of wood structure and properties. Journal of Microscopy 104.

Hylen, G., 1999. Age trends in genetic parameters of wood density in young Norway spruce. Canadian Journal of Forest Research 29, 135-143.

Johnson, G.R., Gartner, B.L., 2006. Genetic variation in basic density and modulus of elasticity of coastal Douglas-fir. Tree Genetics \& Genomes 3, 25-33.

Jozsa, L., Richards, J., Johnson, S., 1987. Calibration of Forintek's direct reading X-ray densitometer. Report No. 36a. Forintek Canada Corp., Vancover, p. 16.

Keller, R., 1973. Caractéristiques du bois de Pin Maritime-Variabilité et Transmission Héréditaire. Annales Science Forestires 30, 31-62.

Koga, S., Zhang, S.Y., 2004. Inter-tree and intra-tree variations in ring width and wood density components in balsam fir (Abies balsamea). Wood Science and Technology 38, 149-162.

Kremer, A., Lascoux, D.M., 1988. Genetic architecture of height growth in maritime pine (Pinus pinaster Ait.). Silvae Genetica 37, 1-8.

Kumar, S., 2004. Genetic parameter estimates for wood stiffness, strength, internal checking, and resin bleeding for Radiata pine. Canadian Journal of Forest Research 34, 2601-2610.

Kumar, S., Burdon, R.D., Stovold, G.T., Gea, L.D., 2008. Implications of selection history on genetic architecture of growth, form, and wood-quality traits in Pinus radiata. Canadian Journal of Forest Research 38, 2372-2381.

Kumar, S., Jayawickrama, K.J.S., Lee, J., Lausberg, M., 2002. Direct and indirect measures of stiffness and strength show high heritability in a wind-pollinated radiata pine progeny test in New Zealand. Silvae Genetica $51,256-261$.

Kusnadar, D., Galwey, N.W., Hertzler, G.L., Butcher, T.B., 1998. Age trends in variances and heritabilities for diameter and height in maritime pine (Pinus pinaster Ait.) in Western Australia. Silvae Genetica 47, 136-141.

Lebourgeois, F., 2000. Climatic signals in earlywood, latewood and total ring width of Corsican pine from western France. Annals of Forest Science 57, 155164

Louzada, J.L.P.C., 2000. Variação fenotípica e genética em características estruturais na madeira de Pinus pinaster Ait. Departamento Florestal, Universidade de Trásos-Montes e Alto Douro, Vila Real, p. 293.

Louzada, J.L.P.C., 2003. Genetic correlations between wood density components in Pinus pinaster Ait. Annals of Forest Science 60, 285-294.

Nicholls, J.W.P., Morris, J.D., Pederick, L.A., 1980. Heritability estimates of density characteristics in juvenile Pinus radiata wood. Silvae Genetica 29, 54-61.

Perez, D.D., Guillemain, A., Alazard, P., Plomion, C., Rozenberg, P., Rodrigues, J.C. Alvess, A., Chantre, G., 2007. Improvement of Pinus pinaster Ait elite trees selection by combining near infrared spectroscopy and genetic tools. Holzforschung 61, 611-622.

Perry, D., Hopkins, E., 1967. Importation of breeding material of Pinus pinaster Ait. from Portugal. For. Dep. W.A. Bulletin 75

Polge, H., 1978. Fifteen years of wood radiation densitometry. Wood Science and Technology 12, 187-196.

Pot, D., Chantre, G., Rozenberg, P., Rodrigues, J.C., Jones, G.L., Pereira, H., Hannrup, B., Cahalan, C., Plomion, C., 2002. Genetic control of pulp and timber properties in Maritime pine (Pinus pinaster Ait.). Annals of Forest Science 59, 563-575.

Rodrigues, J., Alves, A., Pereira, H., Perez, D.D.S., Chantre, G., Schwanninger, M., 2006. NIR PLSR results obtained by calibration with noisy, low-precision reference values: are the results acceptable? Holzforschung 60, 402-408.

Roulund, H., Alpuim, M., Varela, M.C., Aguiar, A., 1988. A Tree Improvement Plan for Pinus pinaster in Portugal. EFN, Lisboa.

Rudman, P., 1968. Growth ring analysis. Journal of the Institute of Wood Science 4 $58-63$.

Saranpää, P., 2003. Wood density and growth. In: Barnett, J.R., Jeronimidis, G. (Eds.), Wood Quality and its Biological Basis. Blackwell Publishing, Victoria, pp. 87-117.

Steffenrem, A., 2008. Genetic Variation in Structural Wood Quality Traits in Norway Spruce and Implications for Tree Breeding. Department of Ecology and Natural Resource Management, Norwegian University of life Sciences.

Sykes, R., Li, B.L., Isik, F., Kadla, J., Chang, H.M., 2006. Genetic variation and genotype by environment interactions of juvenile wood chemical properties in Pinus taeda L. Annals of Forest Science 63, 897-904.

Vargas-Hernandez, J., Adams, W.T., 1991. Genetic-variation of wood density components in young coastal Douglas-Fir-implications for tree breeding. Canadian Journal of Forest Research 21, 1801-1807.

Wimmer, R., Downes, G.M., 2003. Temporal variation of the ring width-wood density relationship in Norway spruce grown under two levels of anthropogenic disturbance. IAWA Journal 24, 53-61.

Wu, H.X., Ivkovic, M., Gapare, W.J., Matheson, A.C., Baltunis, B.S., Powell, M.B. Mcrae, T.A., 2008. Breeding for Wood Quality and profit in Pinus radiata: review of genetic parameter estimates and implications for breeding and deployment. New Zealand Journal of Forestry Science 38.

Yanchuk, A., Kiss, G., 1993. Genetic variation in growth and wood specific gravity and its utility in the improvement of interior spruce in British Columbia. Silvae Genetica 42, 141-148.

Zamudio, F., Rozenberg, P., Baettig, R., Vergara, A., Yanez, M., Gantz, C., 2005. Genetic variation of wood density components in a radiata pine progeny test located in the south of Chile. Annals of Forest Science 62, 105-114. 
Zas, R., Merlo, E., Fernandez-López, J., 2004. Genetic parameter estimates for maritime pine in the Atlantic coast of North-Wet Spain. Forest Genetics 11, 45-53.

Zhang, S.Y., 1997. Variations and correlations of various ring width and ring density features in European oak: implications in dendroclimatology. Wood Science and Technology 31, 63-72.
Zhang, S.Y., Simpson, D., Morgenstern, E.K., 1996. Variation in the relationship of wood density with growth in 40 black spruce (Picea mariana) families grown in New Brunswick. Wood and Fiber Science 28, 91-99.

Zobel, B.J., Jett, J.B., 1995. Genetics of Wood Production, Berlin, Heidelberg, and New York.

Zobel, B.J., van Buijtenen, J.P., 1989. Wood Variation-Its Causes and Control, Berlin. 